\title{
A novel cohabitation between two diazotrophic cyanobacteria in the oligotrophic ocean
}

\author{
Lily M Momper ${ }^{1}$, Brandi Kiel Reese ${ }^{1}$, Gustavo Carvalho, Patrick Lee and Eric A Webb \\ Department of Biological Sciences, Marine Environmental Biology Section, University of Southern California, \\ Los Angeles, CA, USA
}

\begin{abstract}
The cyanobacterial genus Trichodesmium is biogeochemically significant because of its dual role in nitrogen and carbon fixation in the oligotrophic ocean. Trichodesmium species form colonies that can be easily enriched from the water column and used for shipboard rate measurements to estimate their contribution to oceanic carbon and nitrogen budgets. During a July 2010 cruise near the Hawaiian Islands in the oligotrophic North Pacific Subtropical Gyre, a specific morphology of Trichodesmium puff-form colonies were examined under epifluorescent microscopy and found to harbor a colonial endobiont, morphologically identified as the heterocystous diazotrophic cyanobacterium Calothrix. Using unialgal enrichments obtained from this cruise, we show that these Calothrix-like heterocystous cyanobionts (hetDA for 'Trichodesmium-associated heterocystous diazotroph') fix nitrogen on a diurnal cycle (maximally in the middle of the light cycle with a detectable minimum in the dark). Gene sequencing of nifH from the enrichments revealed that this genus was likely not quantified using currently described quantitative PCR (qPCR) primers. Guided by the sequence from the isolate, new hetDA-specific primers were designed and subsequent qPCR of environmental samples detected this diazotroph from surface water to a depth of $150 \mathrm{~m}$, reaching densities up to $\sim 9 \times\left. 10^{3}\right|^{-1}$. Based on phylogenetic relatedness of nifH and 16S rRNA gene sequences, it is predicted that the distribution of this cyanobiont is not limited to subtropical North Pacific but likely reaches to the South Pacific and Atlantic Oceans. Therefore, this previously unrecognized cohabitation, if it reaches beyond the oligotrophic North Pacific, could potentially influence Trichodesmium-derived nitrogen fixation budgets in the world ocean.
\end{abstract}

The ISME Journal (2015) 9, 882-893; doi:10.1038/ismej.2014.186; published online 24 October 2014

\section{Introduction}

Nitrogen $\left(\mathrm{N}_{2}\right)$ fixation is a critical metabolism providing as much as half of the bioavailable nitrogen to ocean surface waters (Montoya et al., 2004; Capone et al., 2005). In the oligotrophic oceans, time-series measurements indicate that $\mathrm{N}_{2}$ fixing bacteria (diazotrophic) can bring more fixed $\mathrm{N}$ into surface waters than upwelling of $\mathrm{NO}_{3}^{-}$(Karl et al., 1997; Dore et al., 2002). As phytoplankton in the oligotrophic ocean are frequently nitrogen $(\mathrm{N})$ limited, the fixed nitrogen provided by diazotrophs is a key controlling factor for marine primary production (Capone et al., 1997; Falkowski et al., 1998; Hutchins et al., 2007; Sohm et al., 2011) and long-term carbon sequestration (Sarmiento et al., 2006; Gruber and Galloway, 2008).

Correspondence: EA Webb, Department of Biological Sciences, Marine Environmental Biology Section, University of Southern California, 3616 Trousdale Parkway, Los Angeles, CA 90089-0371, USA.

E-mail: eawebb@usc.edu

${ }^{1}$ Co-first authors.

Received 18 April 2014; revised 24 July 2014; accepted 30 July 2014; published online 24 October 2014
Biologic $\mathrm{N}_{2}$ fixation is an exclusively prokaryotic process mediated by the nitrogenase enzyme complex, the site where dinitrogen gas is reduced to form two ammonium ions (Postgate, 1982). The nitrogenase enzyme has been described in both heterotrophic and autotrophic organisms spanning the bacterial and archaeal domains (Zehr et al., 2003), but no eukaryotes have been identified that can fix nitrogen without the aid of a prokaryotic symbiont (Sohm et al., 2011; Zehr, 2011). Although there are many genes involved in the nitrogen fixation pathway, the active enzymes are encoded by the functional genes nifH, nifD and nifK (Postgate, 1982). The nifD and nifK genes encode dinitrogenase, the Mo-Fe containing tetramer that possesses the active site for $\mathrm{N}_{2}$ reduction (Mortenson and Thorneley, 1979), whereas the nifH gene encodes dinitrogenase reductase, the iron-containing protein component in the nitrogenase enzyme complex. Amplification, cloning and sequencing of the nifH gene has provided a powerful molecular tool for assessing the diversity of marine organisms capable of bringing new $\mathrm{N}$ into the photic marine ecosystem (Zehr et al., 1998; Zehr, 2011). Field data from many groups have shown that marine cyanobacterial diazotrophs can be delineated into five groups: UCYN-A (a unicellular symbiont to a 
eukaryotic alga), Group B (e.g. Crocosphaera spp.), Group C (e.g. Cyanothece spp.), non-heterocystous filamentous forms (Trichodesmium spp.) and the heterocystous filamentous forms (e.g. Richelia, Calothrix) (Foster et al., 2006; Moisander et al., 2010; Sohm et al., 2011; Zehr, 2011; Thompson et al., 2012).

The Trichodesmium genus is comprised of four distinct clades based on functional and ribosomal genetic analysis: (I) Trichodesmium spiralis, $T$. thiebautii, T. hildebrandtii; (II) novel/uncultured; (III) T. erythraeum; and (IV) T. tenue, T. contortum (Lundgren et al., 2005; Hynes et al., 2012). T. spiralis was previously named Katagnymene spiralis and under this description was found to span the subtropical North and South Pacific Oceans, at certain stations and depths constituting $100 \%$ of the Trichodesmium/Katagnymene morphologically characterized, biomass (Lundgren et al., 2001). Trichodesmium spp. have been known to form blooms throughout the nitrogen-limited Atlantic and Pacific Oceans (Letelier and Karl, 1996), as well as the Arabian and Red Seas (Marvin-DiPasquale and Capone, 1998; Post et al., 2002). In the North Pacific Subtropical Gyre, Trichodesmium spp. dominate a recurring annual phytoplankton bloom (Dore et al., 2008). Despite decades of study, oceanic molecular surveys of Trichodesmium spp. frequently identify signatures from unidentified Trichodesmium phylotypes in field samples, demonstrating that not all members of this group have been recognized or characterized (Janson et al., 1999; Lundgren et al., 2005; Hynes et al., 2009; Chappell et al., 2012). Furthermore, relatively little is known about the distribution, specific microbial associations, enumeration and contribution of each of these phylotypes to Trichodesmium-specific global oceanic $\mathrm{N}_{2}$ fixation (Hmelo et al., 2012).

In addition to Trichodesmium, filamentous, heterocystous diazotrophs (including both free-living and symbiotic cell types) have been detected throughout the North Pacific Subtropical Gyre in

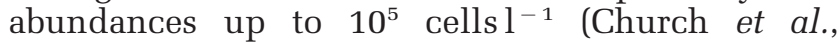
2005a,b, 2008; Foster et al., 2006; Zehr et al., 2007). Three distinct groups of heterocystous diazotrophs have been detected in the North Pacific subtropical ocean: Het_1, Het_2 and Het_3 (the latter aligning with other members of the heterocystous genus Calothrix in sequence analysis) (Church et al., 2005a, 2008; Karl et al., 2008). The previously described heterocystous diazotrophs Richelia spp. and Calothrix spp. have been detected throughout the North Pacific Subtropical Gyre (Church et al., 2008; Foster et al., 2010) and are almost exclusively found in association with the diatoms Rhizosolenia spp. and Chaetoceros spp. (Foster et al., 2006, 2011), respectively. These diatom-diazotroph associations are well documented and globally distributed through the oligotrophic ocean and are thought to have an important role in carbon sequestration (Venrick, 1974; Janson et al., 1999; Subramaniam et al., 2008; Karl et al., 2012; Villareal et al., 2012).
In this study, we report the characterization of a heterocystous diazotroph, not previously observed or enumerated, cohabitating with colonies of the abundant and cosmopolitan global nitrogen fixer Trichodesmium. The heterocystous diazotroph (hetDA for 'Trichodesmium-associated heterocystous diazotroph') will be referred to as a hetDA 'cyanobiont' hereafter because it is currently the most accurate description when one considers that the absolute nature of the association (i.e., parasitic/symbiotic/opportunistic) is still unknown. We quantified the in situ abundance of the new hetDA cyanobiont via nifH gene using quantitative PCR (qPCR), enumerated the ratio of Trichodesmium spp. colonies cohabitating with this cyanobiont and measured the $\mathrm{N}_{2}$-fixation rates from a hetDA enrichment in controlled laboratory conditions.

\section{Materials and methods}

Field sampling

Sampling in the subtropical North Pacific Ocean was conducted aboard the R/V Kilo Moana on a 10-day cruise (KM10-13) near Station ALOHA $\left(22^{\circ}\right.$ $45^{\prime} \mathrm{N}, 158^{\circ} 00^{\prime} \mathrm{W}$ ) in July 2010. Samples for in situ environmental DNA extraction were collected from a Sea Bird CTD (conductivity temperature depth) rosette. Ten liters of seawater were gravity filtered onto $10-\mu \mathrm{m}$ polycarbonate filters from Niskin bottles triggered at discrete depths $(5,25,45,75,125,150$ and $175 \mathrm{~m}$ ). Samples were frozen and stored in liquid nitrogen until DNA extraction using MoBio PowerPlant DNA Isolation Kit (MoBio Laboratories, Carlsbad, CA, USA), and amended with an initial liquid nitrogen freeze/thaw cycle to facilitate cell lysis. Environmental DNA was stored at $-20^{\circ} \mathrm{C}$ and later used for genomic DNA PCR, cloning and sequencing, as well as qPCR enumeration.

Colonies of Trichodesmium spp. were enriched from the top $10 \mathrm{~m}$ with a $130-\mu \mathrm{m}$ mesh plankton net (Sea-Gear Corporation, Melbourne, FL, USA) that was hand towed at the surface for 20-30 min using a $30 \mathrm{~m}$ line. Immediately following the final haul to the surface, the contents of the tow were poured into $5 \mathrm{l}$ polycarbonate beakers and taken into the laboratory. Individual Trichodesmium colonies were carefully handpicked using a polypropylene transfer bulb pipette and then gently washed several times with $0.2-\mathrm{mm}$-filtered local seawater, to remove organisms not closely associated with the colonies before observation on a Zeiss Axiostar epifluorescent microscope with the Zeiss Axiovision software/Axiocam and Zeiss dissecting microscope (Zeiss, Pleasanton, CA, USA).

All hand-picked Trichodesmium colonies were screened for hetDA cells using epifluorescent microscopy. Colonies with the cohabitation were collected and filtered onto a $5.0 \mu \mathrm{m}$ polycarbonate filter and frozen in liquid nitrogen for further 
laboratory analysis (Figure 1). After microscopic confirmation of cohabitation, select individual colonies were placed in $14 \mathrm{ml}$ VWR Polystyrene Culture Tubes containing $10 \mathrm{ml}$ of $0.2 \mu \mathrm{m}$ sterilized YBCII media and incubated on board ship at $24^{\circ} \mathrm{C}$ on a 12:12 h light-dark cycle. Upon return, tubes were immediately placed into a Percival incubator (Percival Scientific Inc., Perry, IA, USA) at $24^{\circ} \mathrm{C}$ and mimicking day-night conditions of $100 \mu \mathrm{mol}$ photons $\mathrm{m}^{-2} \mathrm{~s}^{-1}$ during the $12 \mathrm{~h}$ light cycle. After 1 month, visibly dark green filamentous growth was observed in tube KM1013-14. This enrichment culture was maintained in sterile YBC II media and transferred to fresh YBCII media every 14 days. To purify the filamentous, heterocystous cells, the culture was filtered through a $60 \mu \mathrm{m}$ cell strainer. Cell aggregates were retained and this enrichment was maintained as a semicontinuous batch culture throughout the study. Once the enrichment was stably maintained in the laboratory, the material was streaked on Sigma 1\% tissue culture grade, Type VII agar, YBCII plates to obtain clonal, unialgal hetDA cultures.

\section{DNA extraction and $16 S$ and nifH cloning and sequencing}

To phylogenetically identify the hetDA cells in the culture, 16S rRNA and nifH genes were amplified, cloned and sequenced from genomic DNA extracted from the enrichment using the same procedure as the environmental depth profiles (see above). Primers CYA $106 \mathrm{~F}$ and $781 \mathrm{a} / \mathrm{b}$, which amplify a conserved 16S ribosomal DNA cyanobacteria-specific region, were used as described previously (Nubel et al., 1997). The nifH partial gene sequence was amplified using the primers and nested PCR protocol as described by Zehr and Turner (2001). Primer sequences are found in Table 1. Nuclease-free water additions were used for negative controls and all reactions were performed on an Applied Biosystems 9700 thermocycler (Life Technologies, Carlsbad, CA, USA). Amplicons were separated on $1.2 \%$ agarose gels, DNA bands were visualized using SYBR-safe (Invitrogen, Carlsbad, CA, USA) and desired products purified with QIAquick Gel Purification Kit (Qiagen, Valencia, CA, USA) following the manufacturer's instructions. The purified product was
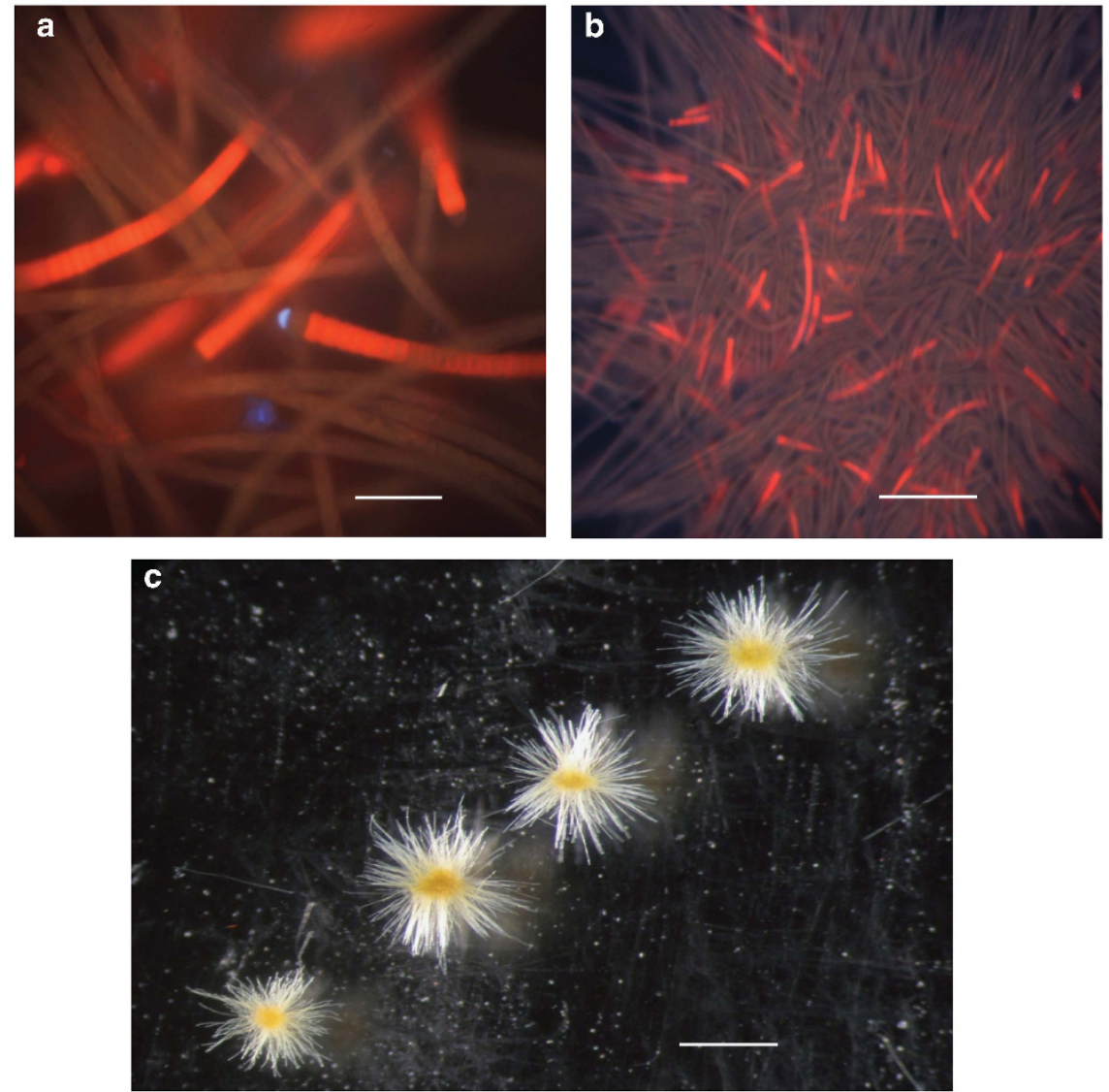

Figure 1 Epifluorescent images of Trichodesmium and heterocystous cyanobiont taken while on board the R/V Kilo Moana in July of 2010. (a) DAPI (4',6-diamidino-2-phenylindole) long-pass filter set micrograph of heterocystous cyanobacterium (bright red tapered filament, bulbous heterocyst, blue cap) and thinner, lighter Trichodesmium filaments. Scale bar is $10 \mu \mathrm{m}$. (b) Same Trichodesmium colony as pictured in (a), at lesser magnification. Shorter, bright red filaments are the heterocystous cyanobacteria, surrounded by longer, thinner Trichodesmium filaments. Scale bar is $50 \mu \mathrm{m}$. (c) Image taken under dissecting microscope. Colonies were handpicked from onboard net-tow and each was confirmed to contain cyanobionts using the epifluorescent microscope. Scale bar is $4 \mathrm{~mm}$. Dark centers are concentrated with hetDA Calothrix-like cyanobionts. 
cloned using the TOPO-TA 2.1 Kit (Invitrogen) and transformed clones were picked for plasmid miniprep using the PureLink Quick Plasmid Miniprep Kit (Invitrogen). Purified minipreps (500 ng) were amplified with T3 and T7 primers $\left(5 \mathrm{pmol} \mathrm{ml}^{-1}\right)$ following the manufacturer's instructions, and sent to Genewiz sequencing facility (San Diego, CA, USA) for Sanger sequencing using $\mathrm{T} 3$ and $\mathrm{T} 7$ forward and reverse primers, respectively.

Sequences were trimmed, assembled and aligned using the MUSCLE algorithm. Phylogenetic trees were created using Geneious Pro version 5.6.2 (Biomatters Ltd., San Francisco, CA, USA). PhyML consensus trees were constructed (Guindon and Gascuel, 2003) using the Jukes Cantor genetic distance model with 1000 bootstrap replicates. Trees were constructed using nucleotide sequences for each of the $16 \mathrm{~S}$ rRNA partial gene sequence ( $681 \mathrm{bp}$ ), and the nifH partial gene sequence (321 bp) (Figures 2a and b), respectively. Sequences from heterocystous cyanobacteria groups traditionally found at Sta. ALOHA were included in Figure $2 b$ to determine whether hetDA had been sequenced in previous diazotroph surveys (Church et al., 2008). The 16S rRNA and nifH sequences obtained in this study have been deposited into NCBI GenBank Short Read Archive under accession numbers KJ093757 and KJ721229, respectively.

\section{Quantitative PCR}

Real-time qPCR $(25 \mu \mathrm{l}$ total volume, reaction conditions: $95^{\circ} \mathrm{C}$ for $5 \mathrm{~min}, 40$ cycles of $95^{\circ} \mathrm{C}$ for $30 \mathrm{~s}$, $48^{\circ} \mathrm{C}$ for $45 \mathrm{~s}, 70^{\circ} \mathrm{C}$ for $30 \mathrm{~s}$ standard melt curve at the end) was performed on environmental DNA extracts at depths from 5 to $175 \mathrm{~m}$ on an Applied Biosystems StepOnePlus Real Time PCR system and processed using StepOne Software Version 2.1 (Applied Biosystems, Foster City, CA, USA) as previously described (Reese et al., 2014). DNA was amplified with the QuantiTect SYBR Green PCR Kit (Qiagen, Valencia, CA, USA) using the KM1013$14 \mathrm{~F} / \mathrm{R}$ primers given in Table 1 . Standards were made from linearized plasmids containing the $237 \mathrm{bp}$ gene fragment of interest, which was cloned from amplified hetDA DNA extracted from

Table 1 Primer nucleotide sequences used for PCR and qPCR analyses

\begin{tabular}{llll}
\hline Primer names & Forward primer $5^{\prime} \rightarrow 3^{\prime}$ & Reverse primer $5^{\prime} \rightarrow 3^{\prime}$ & Gene target/assay \\
\hline nifH $3 /$ nifH 4 & ATRTTRTTNGCNGCRTA & TTYTAYGGNAARGGNGG & nifH/PCR \\
nifH $1 /$ nifH 2 & TGYGAYCCNAARGCNGA & ANDGCCATCATYTCNCC & nifH/PCR \\
KM1013-14F/R & CCAAAGCACAAACAACCGTA & CCACCACATACAACGTCACC & nifH/qPCR \\
Het_3F/R or SC01F/R & CGGTTTCCGTGGCGTACGTT & AATACCACGACCAGCACAAC & nifH/qPCR \\
CYA106F/CYA781a/b & CGGACGGGTGAGTAACGCGTGA & GACTACTGGGGTATCTAATCCCATT & 16S/PCR \\
& & GACTACAGGGGTATCTAATCCCTTT \\
\hline
\end{tabular}

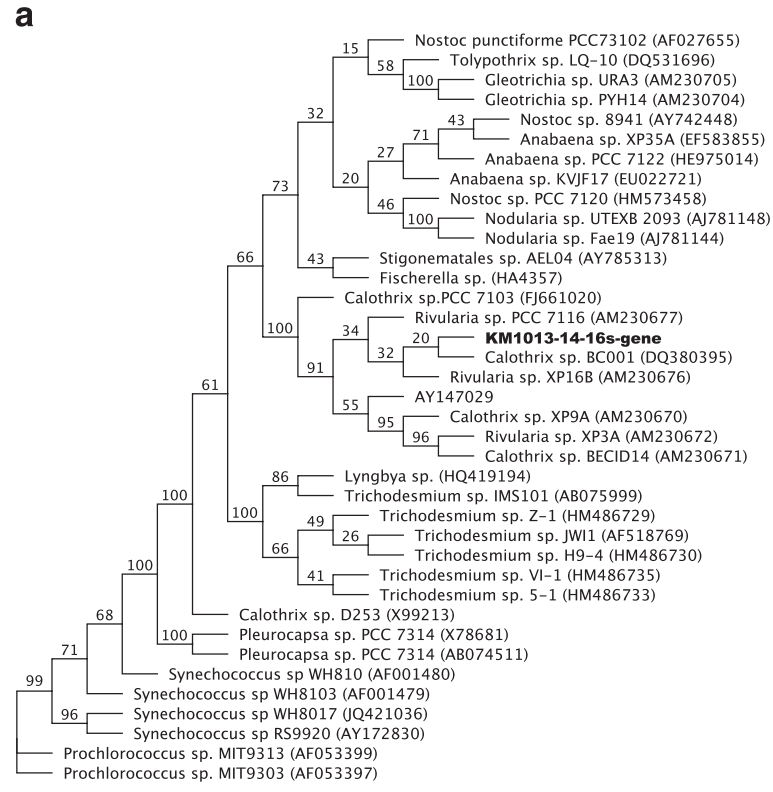

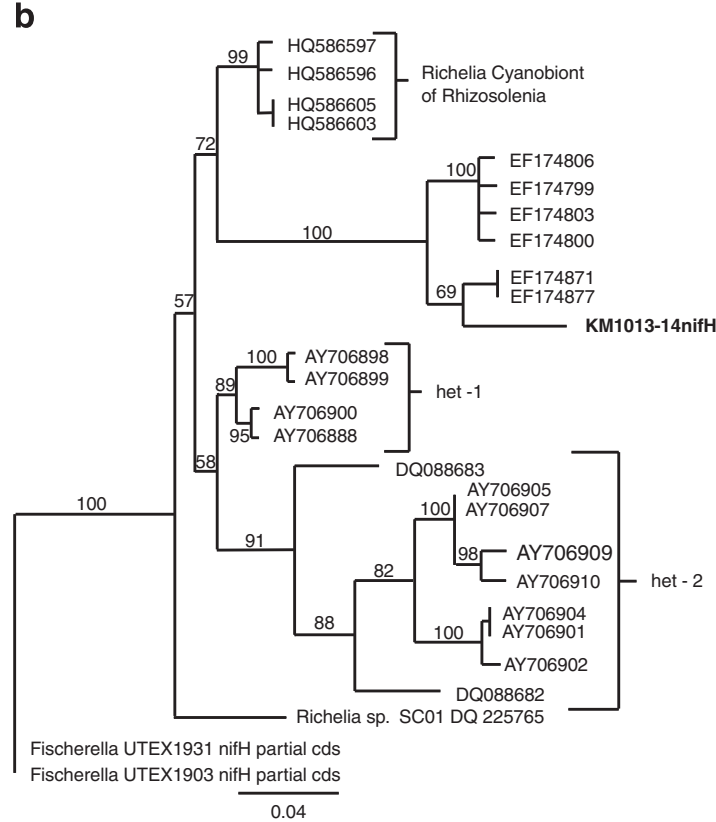

Figure 2 Maximum-likelihood consensus trees relating hetDA cloned $16 \mathrm{~S}$ and nifH sequences to environmental clones and isolates. PhyML trees were constructed in Geneious Pro version 5.6.2 using the Jukes Cantor distance model and 1000 bootstrap replicates. (a) Community 16S rRNA relatedness based on $681 \mathrm{bp} 16 \mathrm{~S}$ rRNA nucleotide sequence. (b) Phylogenetic tree of nifH gene nucleotide sequence relating hetDA enrichment culture to known heterocystous cyanobacteria found in the oligotrophic North Pacific (groups het_1, het_2 and het_3) as well as clones of similar sequence distributed globally. 
laboratory enrichment culture. Standard plasmids were quantified using a Qubit fluorometer (Applied Biosystems) and diluted over six orders of magnitude $\left(1.6 \times 10^{1}-1.6 \times 10^{6}\right)$ with three replicates at each dilution. Sensitivity was calculated with precision to $10^{1}-10^{2}$ target molecules per reaction. No-template negative controls were carried out and yielded no detectable signals. Primer concentration was optimized at $150 \mathrm{~nm}$ to eliminate primer dimer and non-target melt curves. Copy number was calculated assuming a molecular mass of $660 \mathrm{Da}$ per base pair of DNA and using the following formula for calculating the PCR target copy number (Jin and Mattes, 2010):

$$
\frac{\text { gene copies }}{\text { lofwater }}=\frac{\text { concentration }\left(\frac{\mathrm{ng}}{\mu \mathrm{l}}\right) \times \frac{6.022 \times 10^{23}}{\mathrm{~mol}}}{\text { amplicon size }\left(\frac{\mathrm{bp}}{\text { gene copy }}\right) \times \frac{10^{9} \mathrm{ng}}{\mathrm{g}} \times \frac{660 \mathrm{~g}}{\mathrm{~mol}}}
$$

\section{Primer design}

Primers were designed using Serial Primer 3.0 and verified using the NCBI Basic Local Alignment Search Tool (BLAST) database, including environmental clones, for specificity. Previously described SC01/Het_3 primers (Foster and Zehr, 2006; Foster et al., 2010), Het_1 primers (Church et al., 2005b) and Het_2 primers (Church et al., 2008) were tested on nucleic acids extracted from the enriched KM1013-14 culture to ensure that these primers did not amplify hetDA. No amplification was seen using the Het_1, Het_2 or SC01/Het_3 primer sets (data not shown). Amplification of the KM1013-14 nifH gene was observed using the nifH qPCR primers designed specifically for this study, KM1013-14F and R (Table 1). To further test the specificity of the newly designed nifH primers, a clone library was generated from environmental DNA extracts from stations 1 and 2 (Figure 3) collected on the R/V Kilo Moana. Briefly, the clone library was generated as follows: whole environmental template DNA was amplified using our optimized qPCR conditions and primers (excluding the final melt curve), the resulting PCR products were cloned and sequenced as above.

\section{Laboratory $\mathrm{N}_{2}$-fixation rate}

The nitrogenase activity of the hetDA enrichment was evaluated via the acetylene reduction (AR) assay (Capone, 1993). All cultures were grown in autoclaved, sterilized YBCII media with no added nitrogen sources according to the protocol described in Chen et al., 1996. Nitrogen fixation was measured on the hetDA batch culture over a 26-h incubation period (Capone, 1993; Fu et al., 2008). Briefly, immediately before acclimation for the AR assay, whole water enrichments of the hetDA culture were filtered through $60 \mu \mathrm{m}$ cell tissue strainers and only aggregates of dark green filamentous hetDA cells were retained, to ensure there would be minimal

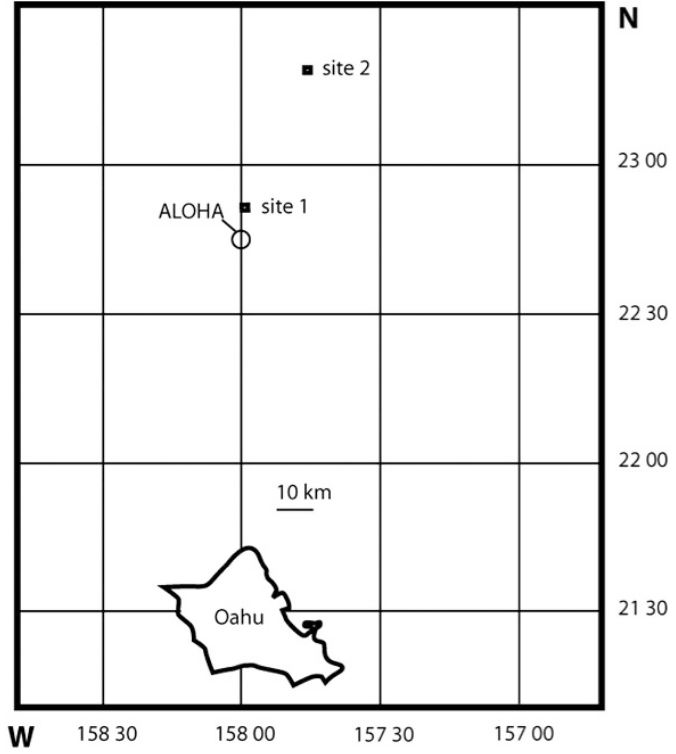

Figure 3 Map of sample collection locations from 17-19 July 2010 on cruise KM10-13. Open circle indicates Station ALOHA $\left(22^{\circ} 45^{\prime} \mathrm{N}, 158^{\circ} 00^{\prime} \mathrm{W}\right)$, small solid squares represent locations where CTD rosette and Niskin bottles were deployed. Longitude and latitude (degrees and minutes) indicated on figure axes.

contamination from potential single-celled cyanobacterial diazotrophs. After filtration, aggregates were transferred back into fresh, sterile YBC II media and $80 \mathrm{ml}$ of this semicontinuous enrichment culture was aliquoted into glass serum vials, placed back in the incubator and allowed to acclimate. Cultures were incubated at $24{ }^{\circ} \mathrm{C}$ with a light-dark cycle of $12: 12 \mathrm{~h}$ and an incident photon flux density of $175 \mu \mathrm{mol}$ photons $\mathrm{m}^{-2} \mathrm{~s}^{-1}$. Vials were then capped with butyl rubber stoppers and crimp sealed. Headspace of vials was sequentially spiked with $5 \mathrm{ml}$ acetylene (time $=0$ ) and evolution of ethylene gas was measured by gas chromatography every hour for $3 \mathrm{~h}$ in biologic triplicate. Ethylene evolution was measured on a Shimadzu gas chromatograph model GC-8A using a flame ionization detector (Shimadzu Scientific Instruments, Columbia, MD, USA) and $200 \mu \mathrm{l}$ injection volume (Chappell and Webb, 2010).

Total chlorophyll was extracted and AR rates were normalized to fluorometrically measured chlorophyll $a(\mathrm{Chl} a)$. Following each AR assay, cultures were filtered onto combusted Whatman GF/F (Fisher Scientific, Pittsburg, PA, USA), placed in 90\% acetone and incubated overnight in the dark at $-20^{\circ} \mathrm{C}$ to extract the Chla. Total Chla was quantified based on the fluorescence technique (Parsons et al., 1984) using a Turner Designs TD-700 fluorometer (Turner Designs, Sunnyvale, CA, USA). Outliers in biologic triplicates were identified using R version 2.9.0 (http://www.r-project.org/).

\section{Results}

Field and laboratory observations

While on board the RV Kilo Moana, a total of 441 Trichodesmium puff colonies were handpicked from 
net tows and screened on the Zeiss epifluorescent microscope using a DAPI (4',6-diamidino-2-phenylindole) long-pass filter. Of these, 347 , or $\sim 75 \%$, were found to contain the unidentified phycocyaninrich, heterocystous cyanobiont (hetDA). The hetDA cells were not observed cohabitating with tuft colonies, thereby indicating potential morphologic specificity. Trichodesmium trichomes appeared orange because of the presence of the photopigment phycoerythrin, whereas the heterocystous cyanobionts were a distinct red, tapered, filament that had a well-defined heterocyst at one end, and a blue cap at the 'top' of the heterocyst (Figure 1a). It was also noted that when the net tow receptacle was left for a short time without agitation, all of the Trichodesmium puff colonies that sank to the bottom of the receptacle contained the hetDA cyanobiont. This sinking indicates reduced colony buoyancy when cyanobionts are present. There appeared to be no size discrimination in cohabitation by the cyanobiont: Trichodesmium colonies that contained the cyanobiont ranged from smallest observed to largest observed, 1.4-3.4 mm diameter (Figure 1c).

Attempts to reconstitute the cohabitation in laboratory cultures were performed with multiple successes. YBCII media (Chen et al., 1996) were not conducive to reconstitution. However, SO media, consisting of $75 \%$ seawater and $25 \%$ MilliQ water, and devoid of a fixed nitrogen source (Webb et al., 2001), exhibited repeated success. Attempts were made with two distinct $T$. thiebautii isolates VI-1 and H9-4 (Hynes et al., 2012). Both Trichodesmium strains demonstrated a propensity to incorporate hetDA filaments into puff colonies within $48 \mathrm{~h}$ of culture combination. In the first $24 \mathrm{~h}$, Trichodesmium spp. and hetDA cells remained physically separate (Figure $4 \mathrm{a}$ ), but during days $2-4$ the hetDA cells were incorporated into healthy Trichodesmium puff colonies (see Figure 4b). After this window, the Trichodesmium filaments tended to be outcompeted by hetDA in culture and gradually died off, until only dark green Calothrix-like filaments could be seen. Attempts to coculture members of the Trichodesmium clade III (specifically, type strain IMS101) with the hetDA cyanobiont were never successful, regardless of media and culture conditions.

\section{Genotypic identification and analyses}

Using total genomic DNA extracted from the laboratory hetDA enrichment, the nifH and 16S rRNA, and genes were PCR amplified, cloned and Sanger sequenced. BLAST comparisons were performed to identify the nucleotide and amino-acid sequences in NCBI, with the highest sequence identity to those amplified from the hetDA enrichment. Amino-acid level comparison of the hetDA nifH partial sequence (324 bp) indicated that heterocystous cyanobacterium culture C1C5 (accession number AF227947), obtained from enriching $\mathrm{N}_{2}$-fixing organisms from Bahamian stromatolites (Steppe et al., 2001) was 99\% identical at the amino-acid level. Interestingly, the nifH hetDA nucleotide sequence did not identify most closely with Bahamian sequence (AF227947), but instead was more similar to putative heterocystous cyanobacterial nifH sequences (95\% nucleotide sequence identity over $317 \mathrm{bp}$, accession numbers EF174877 and EF174871), obtained from Heron Island in the Great Barrier Reef area of the South Pacific (Hewson et al., 2007). This is demonstrated in the resulting phylogenetic tree (Figure 2b) where KM1013-14 and environmental clone EF174877 fall into the same branch with $69 \%$ bootstrap support. Staying within the same branch of the Nostocales, the top cultured hits ( $>98 \%$ nucleotide sequence identity) for the $750 \mathrm{bp}$ hetDA $16 \mathrm{~S}$ rRNA gene sequence include either Rivularia or Calothrix spp. that had been enriched from marine carbonate rock surfaces in Puerto Rico (Calothrix sp. BC001), littoral zone of the Baltic Sea (Rivularia sp. XP16B) or from a small planktonic marine cyanobacterial colony in La Paz, Baja California (Rippka et al., 1979; Chacón et al., 2006; Sihvonen et al., 2007) (Figure 2a). In all of the aforementioned studies, the apparent habitat for the closest hits to hetDA were surface associated or aggregated organisms, findings that are consistent with the hetDA-Trichodesmium aggregate observed at Sta. ALOHA.

Trichodesmium colonies known to contain the heterocystous cyanobiont were screened and collected during cruise KM10-13 (see Materials and methods). DNA was extracted from these colonies and the nifH partial gene sequence was amplified and cloned. Fourteen clones were trimmed and assembled using a CLUSTALW alignment with gap open cost of 15 . The 14 clones generated had $>99 \%$ nucleotide sequence identity. The consensus identity sequence was used to search the NCBI database for closest relatives of the environmental clones. Nucleotide sequence search (BLASTn), excluding environmental clones, of the consensus sequence returned K. spiralis (now T. spiralis), T. erythraeum and T. thiebautii as the closest relatives represented in culture (99\%, 98\% and 98\% identical, respectively).

\section{Quantitative PCR}

Samples were analyzed in triplicate technical replicates at each depth and values were within a standard deviation of 5\% (Supplementary Figure 1). Overall, an average of $10^{2}$ copies nifH gene $\mathrm{l}^{-1}$ was measured at site 1 , and $10^{3}$ copies nifH $1^{-1}$ at site 2 (Table 2). A peak in the number of copies was observed at $75 \mathrm{~m}$ at site 1 . Below $75 \mathrm{~m}$, the number of copies was below the limit of detection ( $10^{1}$ gene copies per reaction). Site 2 showed a higher gene copy number for all depths and a peak cell density at $100 \mathrm{~m}\left(8.7 \times 10^{3}\right.$ copies nifH $\left.\mathrm{l}^{-1}\right)$. Based on a two-way analysis of variance, experimental values for gene copy number were not significantly different between the two sites. Standard curves were run in triplicate with each environmental depth profile and yielded between 

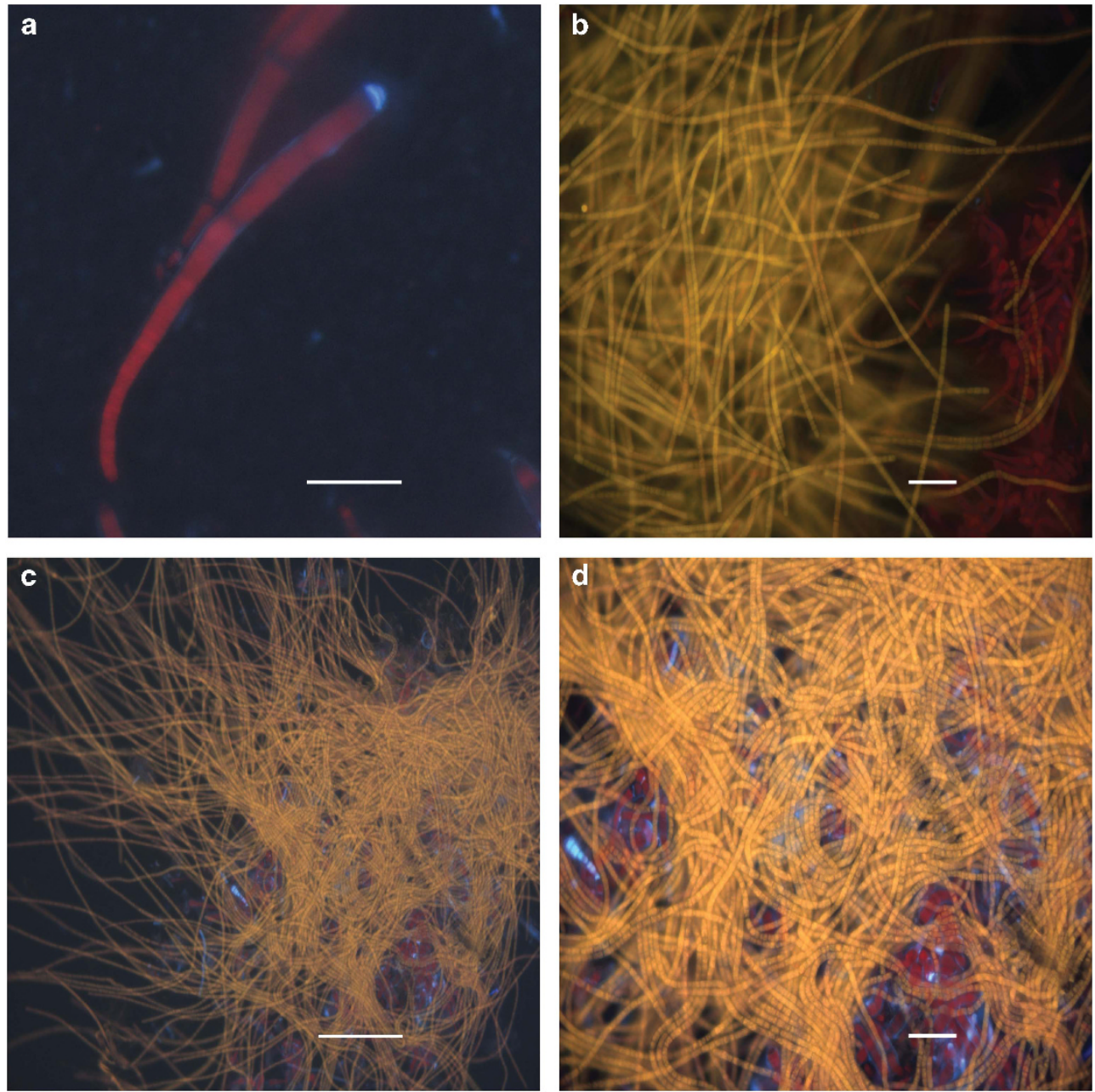

Figure 4 Epifluorescent images of Trichodesmium H9-4 and hetDA maintained and reconstituted in laboratory culture. All images were taken through DAPI (4',6-diamidino-2-phenylindole) long-pass filter (a) hetDA heterocystous filaments by themselves, observed after 2 years in laboratory culture. Scale bar bottom left is $10 \mu \mathrm{m}$. (b) Trichodesmium H9-4 and hetDA filaments after $24 \mathrm{~h}$ in the same liquid culture vessel. Filaments are not yet physically intertwined, but the majority of puff colonies were observed to have the heterocystous cyanobionts clinging to their fringes. Scale bar is $40 \mu \mathrm{m}$. (c) Trichodesmium H9-4 and hetDA after $48 \mathrm{~h}$ in the same culture bottle. Colony was taken from the same liquid culture as the colony pictured in (b). Heterocystous filaments are clearly intertwined in the Trichodesmium H9-4 puff colony. Scale bar is $100 \mu \mathrm{m}$. (d) Image (c) at greater $(\times 400)$ magnification.

95\% and 105\% efficiency and a linear regression through $10^{1}$ copies per reaction (Supplementary Figure 1). Fourteen clones were generated from the qPCR product. They aligned to each other over $247 \mathrm{bp}$ with $<1 \%$ base pair mismatch, indicating that no unintended targets were amplified.

qPCR values were plotted as a function of depth against cruise metadata for temperature and relative fluorescence units (Supplementary Figure 2). No correlations were found between heterocyst-forming cyanobacteria abundance and temperature, depth or chlorophyll profiles (other than a general decrease in cell abundance below $150 \mathrm{~m}$ ).

\section{Culture $\mathrm{N}_{2}$-fixation rates}

Diel AR was run over the $26 \mathrm{~h}$ period $0000-2400$ 0200 hours, using the same batch culture of hetDA (Figure 5). Each experiment resulted in peak fixation rates of $\sim 4.5-5.5 \mu \mathrm{m} \mathrm{C}_{2} \mathrm{H}_{4} \mathrm{mg}$ Chl $a^{-1} \mathrm{~h}^{-1}$, occurring principally between 1000 and 1400 hours. This value is in accord with previous nitrogen fixation calculations for related heterocystous diazotrophs (Foster et al., 2010, 2011). The minimum ethylene production was between 0.0 and $0.3 \mu \mathrm{m} \mathrm{C}_{2} \mathrm{H}_{4} \mathrm{mg}$ Chl $a^{-1} \mathrm{~h}^{-1}$. The baseline measured rate was slightly higher than this minimum signal during dark hours between 1900 and 2400 hours. This indicates basal background nitrogen fixation carried out by hetDA, which appears to be maintained at a lower, but measureable, rate well into the dark cycle.

\section{Discussion}

To our knowledge, this is the first report of high numbers of heterocystous $\mathrm{N}_{2}$-fixing cyanobacteria cohabitating with Trichodesmium colonies in the 
open ocean. One documented strategy used to optimize energy yields in a nutrient-limited habitat, such as the oligotrophic open ocean, is symbiotic metabolite exchange among microbial consortia (Biebl and Pfennig, 1978; Orphan et al., 2001; Foster et al., 2011; Prokopenko et al., 2013). However, because these two diazotrophic primary producers are presumably competing for the same nutrients and producing the same metabolic byproducts, the nature of this relationship remains unclear. One explanation is that very few grazers are thought to prey on Trichodesmium spp. (Hawser et al., 1992; O’Neil and Roman, 1992, 1994); therefore, these large filamentous colonies offer protective habitat in the open ocean, and they are known to harbor a community of heterotrophic bacteria and other filamentous cyanobacteria (Paerl and Bebout, 1989; Siddiqui et al., 1992; Sheridan et al., 2002; Hewson et al., 2009). Measurements of diurnal

Table 2 Summary of ship location and number of nifH gene copies $\mathrm{l}^{-1}$ seawater as a function of depth at two sample sites

\begin{tabular}{lcc}
\hline Site/date collected & Site 1 & Site 2 \\
& 17 July 2010 & 19 July 2010 \\
\hline CTD cast time & 1630 hours & 2130 hours \\
Latitude (N) & 22.8 & 23.3 \\
Longitude (W) & -157.9 & -157.8 \\
SST $\left({ }^{\circ} \mathrm{C}\right)$ & 25.9 & 25.2 \\
Depth (m) & nifH gene copies & per l \\
5 & $1.6 \times 10^{2}$ & $1.2 \times 10^{3}$ \\
25 & $1.7 \times 10^{2}$ & $2.6 \times 10^{3}$ \\
45 & $3.2 \times 10$ & $5.2 \times 10^{2}$ \\
75 & $1.9 \times 10^{2}$ & $1.4 \times 10^{3}$ \\
100 & BDL & $8.7 \times 10^{3}$ \\
125 & BDL & $1.5 \times 10^{3}$ \\
150 & BDL & $3.5 \times 10^{3}$ \\
175 & BDL & BDL \\
\end{tabular}

nifH values are means of triplicates, standard error $<5 \%$.

Abbreviations: BDL, below detection limit; CTD, conductivity temperature depth; SST, sea surface temperature. nitrogen fixation have shown that Trichodesmium nitrogen-fixation rates drop to below detection level at the start of the dark cycle (e.g., Capone et al., 2005; Staal et al., 2007). However, heterocystous diazotrophs are known to express nifH transcripts into the middle of the dark cycle (Zehr et al., 2007; Poretsky et al., 2009), a time when Trichodesmium are reaching N-storage depletion. Dark cycle, unintentional excretion of fixed bioavailable $\mathrm{N}$ by associated heterocystous cyanobacteria could be an advantage to the Trichodesmium colonies harboring the endosymbiont as Trichodesmium spp. are known to fix nitrogen in the middle of the light cycle but experience $\mathrm{N}$ starvation at night (BermanFrank et al., 2001). According to our AR assay results, the hetDA cyanobionts appear to have a basal rate of nitrogen fixation through the dark cycle. In associated colonies, this could alleviate the $\mathrm{N}$ stress experienced by Trichodesmium cells at night.

Others have calculated the abundance of various heterocystous diazotrophic groups using qPCR of the nifH gene at Sta. ALOHA (e.g., Church et al., 2005a,b, 2008). However, because of specificity of the primers used, we believe that the heterocystous cyanobacterium described in this study was not detected in those previous studies and therefore has not been quantified at Sta. ALOHA or any other location. The relative abundance of the heterocystous cyanobacterial group described in this study is in the range of total heterocystous cyanobacteria cell densities measured previously, $10^{2}-10^{3} \mathrm{l}^{-1}$ (Church et al., 2008), indicating that this new phylotype has a measurable and perhaps significant role in $\mathrm{C}$ and $\mathrm{N}$ cycling in the subtropical North Pacific Ocean. Previous surveys at Sta. ALOHA have quantified average Trichodesmium cell abundance at $10^{5} \mathrm{l}^{-1}$ (Church et al., 2008). Combining previous surveys and the qPCR results reported herein, the relative abundance of Trichodesmium cells to the newly described cyanobiont ranges from 10:1 to 100:1.

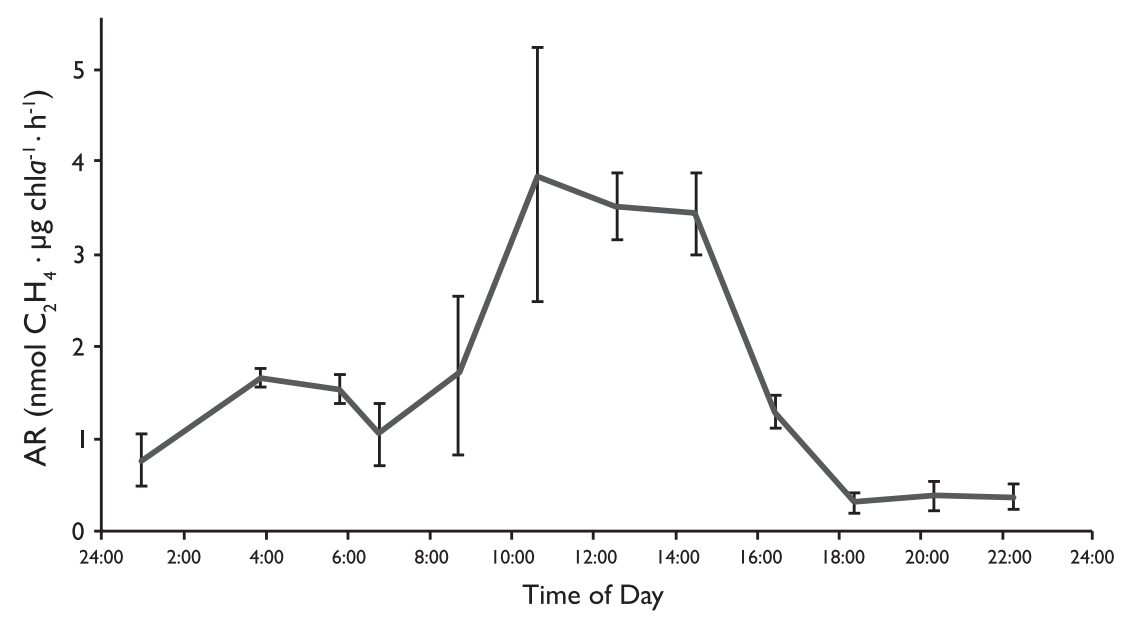

Figure 5 Summary of hetDA enrichment acetylene reduction over the diel cycle. Data points are the means of biologic triplicates at each timepoint. Standard error bars are shown on graph. Sample vial headspace was saturated with acetylene every $2-3 \mathrm{~h}$ and $500 \mu \mathrm{l}$ gas samples were removed from headspace for analysis every hour following acetylene addition. 
The hetDA cyanobiont has yet to be quantified in situ at any location outside the stations surveyed in this study; thus, a wider environmental survey using the nifH qPCR primers designed in this study would elucidate questions on the global importance of these cells.

Based on phylogenetic comparison of the nifH gene nucleotide sequence, the hetDA endosymbiont is most closely related to a heterocystous cyanobacterium found in the South Pacific-Indian Oceans (uncultured environmental clones EF174877 and EF174871) (Hewson et al., 2007). Comparisons made in the NCBI database for $16 \mathrm{~S}$ rRNA nucleotide sequence revealed that closest relatives to hetDA have geographic ranges from the Baltic Sea (i.e. BECID14 accession no. AM230671) (Sihvonen et al., 2007) to the subtropical South Pacific Ocean (i.e. BC001 accession no. 230670) (Hewson et al., 2007). These clones were found in near-island, benthic environments. However, the closely related cells found in this study were collected in the oligotrophic open ocean. It was noted that Trichodesmium colonies that contained the heterocystous cyanobiont sank to the bottom of the collection vessel; however, colonies that did not contain the hetDA cells appeared to be more buoyant. This field result with freshly collected colonies suggests that the hetDA cells have negative buoyancy compared with Trichodesmium, a supposition that was consistent with laboratory observation of hetDA enrichment cultures. It is possible that the hetDA cells are taking advantage of the buoyancy and range of Trichodesmium to exploit a new habitat: the open ocean. Without association with Trichodesmium colonies, the cyanobiont would likely sink out of the photic zone. Furthermore, the dominant lightharvesting pigment of Trichodesmium cells is phycoerythrin, whereas it is phycocyanin in the cyanobiont. Assuming that the light levels were high enough, wavelength partitioning could ensure that the two cell types are not directly competing for available light.

Gliding motility was also observed in the hetDA culture. Field observations showed that cyanobiont cells concentrate in the center of Trichodesmium colonies, and cell motility would indicate that the hetDA cells preferentially inhabits this niche within the colony. It is well known that algae can release significant amounts of recently fixed carbon as molecules and polymers that fall into both the dissolved or particulate phases, and Trichodesmium is no exception (e.g., Nagata, 2000; Berman-Frank et al., 2007; Claquin et al., 2008). In Trichodesmium, this carbon (and presumably N) supports a wide array of heterotrophic organisms (Paerl and Bebout, 1989; Hmelo et al., 2012) with activities so significant that the center of the colonies can go anoxic (Paerl and Bebout, 1988) and even allow the growth of active denitrifying bacteria (Wyman et al., 2013). Oxygen diffusion across the Calothrix-like cyanobionts' heterocystous would be minimized in the oxygen-deplete center of the Trichodesmium colony bundle, thereby lessening cellular damage and nitrogen fixation inhibition. Additionally, it is also known that Trichodesmium moves Fe-rich minerals to the center of the colony where they are subsequently dissolved (Rueter et al., 1992; Rubin et al., 2011). According to $16 \mathrm{~S}$ rRNA gene sequence analysis, Rivularia strain PCC7116 has the highest sequence identity to strain hetDA, and it is known to be a facultative photoheterotroph (Rippka et al., 1979); thus, it is possible that hetDA has photoheterotrophic capabilities as well. And, it is quite possible that the hetDA cells live an opportunistic, photoheterotrophic lifestyle, taking advantage of enriched carbon polymers, fixed nitrogen, dissolved $\mathrm{Fe}$ and low molecular oxygen in the center of Trichodesmium colonies.

Finally, $\mathrm{N}_{2}$-fixing organisms, similar to Trichodesmium, can contribute to long-term carbon sequestration (Sarmiento et al., 2006; Gruber and Galloway, 2008). Here we suggest that the newly documented heterocystous cohabitation could have a role in the previously documented efficiency of $\mathrm{N}_{2}$-fixationmediated downward particle flux (Dore et al., 2002). This is corroborated by the 13-year (19922004) observation of a large and rapid particle export flux at Sta. ALOHA, dubbed the summer export pulse (Karl et al., 2012). This period of high primary productivity include diatom-diazotroph associations and bloom conditions for various phytoplankton, and it is possible that the faster-sinking Trichodesmium colonies harboring the hetDA cyanobiont could contribute to this flux. This pulse occurs principally from 15 July-15 August, exactly overlapping with our observation in July 2010 of Trichodesmium harboring $\mathrm{N}_{2}$-fixing hetDA cyanobionts. Further work at Sta. ALOHA needs to be carried out to test any possible role of hetDA in this downward flux.

\section{Conflict of Interest}

The authors declare no conflict of interest.

\section{Acknowledgements}

This work was supported by National Science Foundation Grants OCE-0962209 and OCE-1260490. We thank the captain and crew of the R/V Kilo Moana and chief scientists Benjamin Van Mooy and Tracy Mincer for inviting us to participate on cruise KM1013 (funded by NSF Grant OCE-0825407).

\section{References}

Berman-Frank I, Lundgren P, Chen Y-B, Küpper H, Kolber Z, Bergman B et al. (2001). Segregation of nitrogen fixation and oxygenic photosynthesis in the marine cyanobacterium Trichodesmium. Science 294: 1534-1537. 
Berman-Frank I, Quigg A, Finkel ZV, Irwin AJ, Haramaty L. (2007). Nitrogen-fixation strategies and Fe requirements in cyanobacteria. Limnol Oceanogr 52: 2260-2269.

Biebl H, Pfennig N. (1978). Growth yields of green sulfur bacteria in mixed cultures with sulfur and sulfate reducing bacteria. Archiv Microbiol 117: 9-16.

Capone D. (1993). Determination of nitrogenase activity in aquatic samples using the acetylene reduction procedure. Handbook Methods Aquat Microb Ecol 200: 621-631.

Capone DG, Zehr JP, Paerl HW, Bergman B, Carpenter EJ. (1997). Trichodesmium, a globally significant marine cyanobacterium. Science 276: 1221-1229.

Capone DG, Burns JA, Montoya JP, Subramaniam A, Mahaffey C, Gunderson T et al. (2005). Nitrogen fixation by Trichodesmium spp.: aan important source of new nitrogen to the tropical and subtropical North Atlantic Ocean. Global Biogeochem Cycles 19; e-pub ahead of print 8 June 2005; doi:10.1029/ 2004GB002331.

Chacón E, Berrendero E, Garcia Pichel F. (2006). Biogeological signatures of microboring cyanobacterial communities in marine carbonates from Cabo Rojo, Puerto Rico. Sediment Geol 185: 215-228.

Chappell PD, Webb EA. (2010). A molecular assessment of the iron stress response in the two phylogenetic clades of Trichodesmium. Environ Microbiol 12: 13-27.

Chappell PD, Moffett JW, Hynes AM, Webb EA. (2012). Molecular evidence of iron limitation and availability in the global diazotroph Trichodesmium. ISME $J$ 6: 1728-1739.

Chen Y-B, Zehr JP, Mellon M. (1996). Growth and nitrogen fixation of the diazotrophic filamentous nonheterocystous cyanobacterium Trichodesmium sp. IMS 101 in defined media: evidence for a circadian rhythm. J Phycol 32: 916-923.

Church MJ, Jenkins BD, Karl DM, Zehr JP. (2005a). Vertical distributions of nitrogen-fixing phylotypes at Stn ALOHA in the oligotrophic North Pacific Ocean. Aquat Microb Ecol 38: 3-14.

Church MJ, Short CM, Jenkins BD, Karl DM, Zehr JP. (2005b). Temporal patterns of nitrogenase gene (nifH) expression in the oligotrophic North Pacific Ocean. Appl Environ Microbiol 71: 5362-5370.

Church MJ, Bjorkman KM, Karl DM, Saito MA, Zehr JP. (2008). Regional distributions of nitrogen-fixing bacteria in the Pacific Ocean. Limnol Oceanogr 53: 63.

Claquin P, Probert I, Sb Lefebvre, Veron BÆ. (2008). Effects of temperature on photosynthetic parameters and TEP production in eight species of marine microalgae. Aquat Microb Ecol 51: 1.

Dore JE, Brum JR, Tupas LM, Karl DM. (2002). Seasonal and interannual variability in sources of nitrogen supporting export in the oligotrophic subtropical North Pacific Ocean. Limnol Oceanogr 47: 1595-1607.

Dore JE, Letelier RM, Church MJ, Lukas R, Karl DM. (2008). Summer phytoplankton blooms in the oligotrophic North Pacific Subtropical Gyre: Historical perspective and recent observations. Progr Oceanogr 76: $2-38$.

Falkowski PG, Barber RT, Smetacek V. (1998). Biogeochemical controls and feedbacks on ocean primary production. Science 281: 200-206.

Foster RA, Carpenter EJ, Bergman B. (2006). Unicellular cyanobionts in open ocean dinoflagellates, radiolarians, and tintinnids: ultrastructural characterization and immuno-localization of phycoerythrin and nitrogenase. J Phycol 42: 453-463.

Foster RA, Zehr JP. (2006). Characterization of diatomcyanobacteria symbioses on the basis of nifH, hetR and 16S rRNA sequences. Environ Microbiol 8: 1913-1925.

Foster RA, Goebel NL, Zehr JP. (2010). Isolation of Calothrix Rhizosoleniae (Cyanobateria) strain SC01 from Chaetoceros (Bacillariophyta) spp. diatoms of the subtropical North Pacific Ocean. J Phycol 46: 1028-1037.

Foster RA, Kuypers MM, Vagner T, Paerl RW, Musat N, Zehr JP. (2011). Nitrogen fixation and transfer in open ocean diatom-cyanobacterial symbioses. ISME $J$ 5: 1484-1493.

Fu F-X, Mulholland MR, Garcia NS, Beck A, Bernhardt PW, Warner ME et al. (2008). Interactions between changing $p \mathrm{CO}_{2},-\mathrm{N}_{2}$ fixation, and $\mathrm{Fe}$ limitation in the marine unicellular cyanobacterium Crocosphaera. Limnol Oceanogr 53: 2472.

Gruber N, Galloway JN. (2008). An Earth-system perspective of the global nitrogen cycle. Nature 451: 293-296.

Guindon Sp, Gascuel O. (2003). A simple, fast, and accurate algorithm to estimate large phylogenies by maximum likelihood. System Biol 52: 696-704.

Hawser S, O’neil J, Roman M, Codd G. (1992). Toxicity of blooms of the cyanobacterium Trichodesmium to zooplankton. J Appl Phycol 4: 79-86.

Hewson I, Moisander PH, Morrison AE, Zehr JP. (2007). Diazotrophic bacterioplankton in a coral reef lagoon: phylogeny, diel nitrogenase expression and response to phosphate enrichment. ISME J 1: 78-91.

Hewson I, Poretsky RS, Dyhrman ST, Zielinski B, White AE, Tripp HJ et al. (2009). Microbial community gene expression within colonies of the diazotroph, Trichodesmium, from the Southwest Pacific Ocean. ISME J 3: 1286-1300.

Hmelo L, Van Mooy B, Mincer T. (2012). Characterization of bacterial epibionts on the cyanobacterium Trichodesmium. Aquat Microbial Ecol 67: 1-14.

Hutchins D, Fu F-X, Zhang Y, Warner M, Feng Y, Portune K et al. (2007). $\mathrm{CO}_{2}$ control of Trichodesmium $\mathrm{N}_{2}$ fixation, photosynthesis, growth rates, and elemental ratios: implications for past, present, and future ocean biogeochemistry. Limnol Oceanogr 52: 1293.

Hynes AM, Chappell PD, Dyhrman ST, Doney SC, Webb EA. (2009). Cross-basin comparison of phosphorus stress and nitrogen fixation in Trichodesmium. Limnol Oceanogr 54: 1438.

Hynes AM, Webb EA, Doney SC, Waterbury JB. (2012). Comparison of cultured Trichodesmium (Cyanophyceae) with species characterized from the field. J Phycol 48: 196-210.

Janson S, Wouters J, Bergman B, Carpenter E. (1999). Host specificity in the Richelia-diatom symbiosis revealed by hetR gene sequence analysis. Environ Microbiol 1: 431-438.

Jin YO, Mattes TE. (2010). A Quantitative PCR assay for aerobic, vinyl chloride- and ethene-assimilating microorganisms in groundwater. Environ Sci Technol 44: 9036-9041.

Karl DM, Letelier R, Tupas L, Dore J, Christian J, Hebel D. (1997). The role of nitrogen fixation in biogeochemical cycling in the subtropical North Pacific Ocean. Nature 388: $533-538$.

Karl DM, Letelier RM, Rickman K, Letelier R. (2008). Nitrogen fixation-enhanced carbon sequestration in 
low nitrate, low chlorophyll seascapes. Mar Ecol Progr Ser 364: 257-268.

Karl DM, Church MJ, Dore JE, Letelier RM, Mahaffey C. (2012). Predictable and efficient carbon sequestration in the North Pacific Ocean supported by symbiotic nitrogen fixation. Proc Natl Acad Sci USA 109: 1842-1849.

Letelier RM, Karl DM. (1996). Role of Trichodesmium spp. in the productivity of the subtropical North Pacific Ocean. Mar Ecol Progr Ser 133: 263-273.

Lundgren P, Soderback E, Singer A, Carpenter EJ, Bergman B. (2001). Katagnymene: characterization of a novel marine diazotroph. J Phycol 37: 1052-1062.

Lundgren P, Janson S, Jonasson S, Singer A, Bergman B. (2005). Unveiling of novel radiations within Trichodesmium cluster by hetR gene sequence analysis. Appl Environ Microbiol 71: 190-196.

Marvin-DiPasquale MC, Capone DG. (1998). Benthic sulfate reduction along the Chesapeake Bay central channel. I. Spatial trends and controls. Mar Ecol Progr Ser 168: 213-228.

Moisander PH, Beinart RA, Hewson I, White AE, Johnson KS, Carlson CA et al. (2010). Unicellular cyanobacterial distributions broaden the oceanic $\mathrm{N}_{2}$ fixation domain. Science 327: 1512-1514.

Montoya JP, Holl CM, Zehr JP, Hansen A, Villareal TA, Capone DG. (2004). High rates of $\mathrm{N}_{2}$ fixation by unicellular diazotrophs in the oligotrophic Pacific Ocean. Nature 430: 1027-1032.

Mortenson LE, Thorneley RN. (1979). Structure and function of nitrogenase. Annu Rev Biochem 48: 387-418.

Nagata T. (2000). Production mechanisms of dissolved organic matter. Microb Ecol Oceans 121-152.

Nubel U, Garcia-Pichel F, Muyzer G. (1997). PCR primers to amplify $16 \mathrm{~S}$ rRNA genes from cyanobacteria. Appl Environ Microbiol 63: 3327-3332.

O’Neil J, Roman M. (1994). Ingestion of the cyanobacterium Trichodesmium spp. by pelagic harpacticoid copepods Macrosetella, Miracia and Oculosetella. Hydrobiologia 292: 235-240.

O’Neil JM, Roman MR. (1992). Grazers and associated organisms of Trichodesmium. In: Marine Pelagic Cyanobacteria: Trichodesmium and Other Diazotrophs. Springer: Berlin, Germany, pp 61-73.

Orphan VJ, House CH, Hinrichs K-U, McKeegan KD, DeLong EF. (2001). Methane-consuming archaea revealed by directly coupled isotopic and phylogenetic analysis. Science 293: 484-487.

Paerl HW, Bebout BM. (1988). Direct measurement of $\mathrm{O}_{2}$-depleted microzones in marine Oscillatoria: relation to $\mathrm{N}_{2}$ fixation. Science 241: 442-445.

Pearl HW, Bebout BM, Prufert LE. (1989). Bacterial associations with marine Oscillatoria sp. (Trichodesmium sp.) populations: ecophysiological implications. J Phycol 25: 773-784.

Parsons TR, Maita Y, Lalli CM. (1984). A Manual of Chemical and Biological Methods for Seawater Analysis. Pergamon Press: New York, NY, USA.

Poretsky RS, Hewson I, Sun S, Allen AE, Zehr JP, Moran MA. (2009). Comparative day/night metatranscriptomic analysis of microbial communities in the North Pacific subtropical gyre. Environ Microbiol 11: 1358-1375.

Post A, Dedej Z, Gottlieb R, Li H, Thomas D, El-Absawi M et al. (2002). Spatial and temporal distribution of
Trichodesmium spp. in the stratified Gulf of Aqaba, Red Sea. Mar Ecol Progr Ser 239: 241-250.

Postgate JR. (1982). The Fundamentals of Nitrogen Fixation. Cambridge University Press: Cambridge, UK.

Prokopenko M, Hirst M, De Brabandere L, Lawrence D, Berelson W, Granger J et al. (2013). Nitrogen losses in anoxic marine sediments driven by Thioplocaanammox bacterial consortia. Nature 500: 194-198.

Reese BK, Witmer AD, Moller S, Morse JW, Mills HJ. (2014). Molecular assays advance understanding of sulfate reduction despite cryptic cycles. Biogeochemistry 118: 307-319.

Rippka R, Deruelles J, Waterbury JB, Herdman M, Stanier RY. (1979). Generic assignments, strain histories and properties of pure cultures of cyanobacteria. J Gen Microbiol 111: 1-61.

Rubin M, Berman-Frank I, Shaked Y. (2011). Dust-and mineral-iron utilization by the marine dinitrogen-fixer Trichodesmium. Nat Geosci 4: 529-534.

Rueter JG, Hutchins DA, Smith RW, Unsworth NL. (1992). Iron Nutrition of Trichodesmium. Marine Pelagic Cyanobacteria: Trichodesmium and other Diazotrophs. Springer: Berlin, Germany, pp 289-306.

Sarmiento G, da Silva MP, Naranjo ME, Pinillos M. (2006). Nitrogen and phosphorus as limiting factors for growth and primary production in a flooded savanna in the Venezuelan Llanos. J Trop Ecol 22: 203-212.

Sheridan C, Steinberg D, Kling G. (2002). The microbial and metazoan community associated with colonies of Trichodesmium spp.: a quantitative survey. J Plankton Res 24: 913-922.

Siddiqui P, Bergman B, Carpenter E. (1992). Filamentous cyanobacterial associates of the marine planktonic cyanobacterium Trichodesmium. Phycologia 31: 326-337.

Sihvonen LM, Lyra C, Fewer DP, Rajaniemi-Wacklin P, Lehtimaki JM, Wahlsten M et al. (2007). Strains of the cyanobacterial genera Calothrix and Rivularia isolated from the Baltic Sea display cryptic diversity and are distantly related to Gloeotrichia and Tolypothrix. FEMS Microbiol Ecol 61: 74-84.

Sohm JA, Webb EA, Capone DG. (2011). Emerging patterns of marine nitrogen fixation. Nat Rev Microbiol 9: 499-508.

Steppe T, Pinckney J, Dyble J, Paerl H. (2001). Diazotrophy in modern marine Bahamian stromatolites. Microb Ecol 41: 36-44.

Staal M, Rabouille S, Stal LJ. (2007). On the role of oxygen for nitrogen fixation in the marine cyanobacterium Trichodesmium sp. Environ Microbiol 9: $727-736$.

Subramaniam A, Yager P, Carpenter E, Mahaffey C, Bjorkman K, Cooley S et al. (2008). Amazon River enhances diazotrophy and carbon sequestration in the tropical North Atlantic Ocean. Proc Natl Acad Sci USA 105: 10460-10465.

Thompson AW, Foster RA, Krupke A, Carter BJ, Musat N, Vaulot D et al. (2012). Unicellular cyanobacterium symbiotic with a single-celled eukaryotic alga. Science 337: 1546-1550.

Venrick E. (1974). The distribution and significance of Richelia intracellularis Schmidt in the North Pacific Central Gyre. Limnol Oceanogr 19: 437-445.

Villareal TA, Brown CG, Brzezinski MA, Krause JW, Wilson C. (2012). Summer diatom blooms in the North Pacific subtropical gyre: 2008-2009. PLoS One 7: e33109. 
Webb EA, Moffett JW, Waterbury JB. (2001). Iron stress in open-ocean Cyanobacteria (Synechococcus, Trichodesmium, and Crocosphaera spp.): identification of the IdiA protein. Appl Environ Microbiol 67: 5444-5452.

Wyman M, Hodgson S, Bird C. (2013). Denitrifying Alphaproteobacteria from the Arabian Sea that express nos $Z$, the gene encoding nitrous oxide reductase, in oxic and suboxic waters. Appl Environ Microbiol 79: 2670-2681.

Zehr J, Turner P. (2001). Nitrogen fixation: Nitrogenase genes and gene expression. Mar Microbiol 30: 271.

Zehr JP, Mellon MT, Zani S. (1998). New nitrogen-fixing microorganisms detected in oligotrophic oceans by amplification of nitrogenase (nifH) genes. Appl Environ Microbiol 64: 3444-3450.

Zehr JP, Jenkins BD, Short SM, Steward GF. (2003). Nitrogenase gene diversity and microbial community structure: a cross-system comparison. Environ Microbiol 5: 539-554.

Zehr JP, Montoya JP, Jenkins BD, Hewson I, Mondragon E, Short CM et al. (2007). Experiments linking nitrogenase gene expression to nitrogen fixation in the North Pacific subtropical gyre. Limnol Oceanogr 52: 169-183.

Zehr JP. (2011). Nitrogen fixation by marine cyanobacteria. Trends Microbiol 19: 162-173.

Supplementary Information accompanies this paper on The ISME Journal website (http://www.nature.com/ismej) 